\title{
Multiple Mucoceles Located in the Nasopharynx and Hypopharynx: Case Report
}

\author{
Nazofarenks ve Hipofarenks Yerleșimli Multipl Mukosel: Olgu Sunumu
}

\author{
Oğuz Oğuzhan', Selman Sarıca², Yusuf Yıldırım³, Mücahit Altınıșık², Abdulkadir Yasir Bahar', Ali Osman Özbey' \\ ${ }^{1}$ Siverek State Hospital, Department of Otorbinolaryngology, Şanlurfa; ${ }^{2}$ Sütçü Imam University, Department of Otorhinolaryngology, \\ Kabramanmaras,; ${ }^{3}$ Necip Fazll City State Hospital, Department of Otorhinolaryngology; ${ }^{4}$ Department of Pathology, Kabramanmaras, \\ Turkey
}

\begin{abstract}
Mucoceles are asymptomatic masses generally located intraorally, that can occur in various diameters and dimensions. In majority of the cases, they are single, but can be rarely multiple. In this case presentation, a very rare case of minor salivary gland mucoceles in a 45-year-old female patient, in the left ariepiglottic fold of the hypopharynx and in the left rosenmüller fossa of the nasopharynx, has been discussed with regard to the diagnosis and treatment in the light of the literature.
\end{abstract}

Key words: mucocele; salivary gland; Rosenmüller fossa; aryepiglottic fold

\section{ÖZET}

Mukoseller değișik çap ve boyutlarda olabilen, genellikle intraoral yerleșimli asemptomatik kitlelerdir. Çoğunlukla tektir ancak ender de olsa multipl olabilmektedir. Bu olgu sunumunda kırk beș yașında bayan hastada, oldukça ender olan nazofarenkste sol rosenmüller fossa ve hipofarenkste sol ariepiglottik foldda minör tükürük bezi mukoseli olgusu tanı ve tedavisi literatür eșliğinde tartıșıldı.

Anahtar kelimeler: mukosel; tükürük bezi; Rosenmüller fossa; aryepiglottik fold

\section{Introduction}

Mucoceles are benign cystic lesions of the salivary glands that can be various diameters and dimensions, can be located superficially or deep, and can be of bluepurple or normal mucosal colour. Although they can be encountered in all places where salivary glands are located, in general they can be observed in the intraoral region, the lateral of the midline in the lower lip, and

Oğuz Oğuzhan, Sanliurfa Siverek Devlet Hastanesi KBB Kliniği Şanlıurfa, Türkiye,Tel.05060279672 Email.oguz_oguz_han@hotmail.com Geliş Taribi: 26.10.2015 • Kabul Taribi: 25.03.2017 on the buccal or palatinal mucosa ${ }^{1,2}$. Mucoceles are usually single, but they might rarely be multiple ${ }^{2}$. The treatment of salivary gland mucocele is surgical excision ${ }^{3}$.

In this report, with regard to the diagnosis and treatment, we aimed to share our case in whom there was symptomatic multiple mucoceles in a minor salivary gland, which were localized in the nasopharynx in the left rosenmüller fossa and in the aryepiglottic fold in the hypopharynx, which is very rarely encountered.

\section{Case}

A 45-year-old female patient presented to our clinic with the complaints of intermittent difficult breathing through the left side of the nose and the feeling of food getting stuck in the throat during swallowing, which had been presented for one year. The physical examination performed on the patient revealed normal findings, and on the endoscopic examination of the nasopharynx and the larynx, a cystic mass was observed in the nasopharynx filling the left rosenmüller fossa and in the left aryepiglottic fold neighboring the epiglottis (Figure 1,2). The laboratory findings were normal and the patient's past medical history was unremarkable.

Under general anaesthesia, using the endoscopic method, the cystic mass filling the left rosenmüller fossa in the nasopharynx was marsupialized, and in laryngoscopy, the cystic mass in the left aryepiglottic fold neighboring the epiglottis was totoally excised under microscopy. The pathology of the excision material was reported as a salivary gland mucocele (Figure 3). No recurrence was observed on the follow-ups performed for two years. 


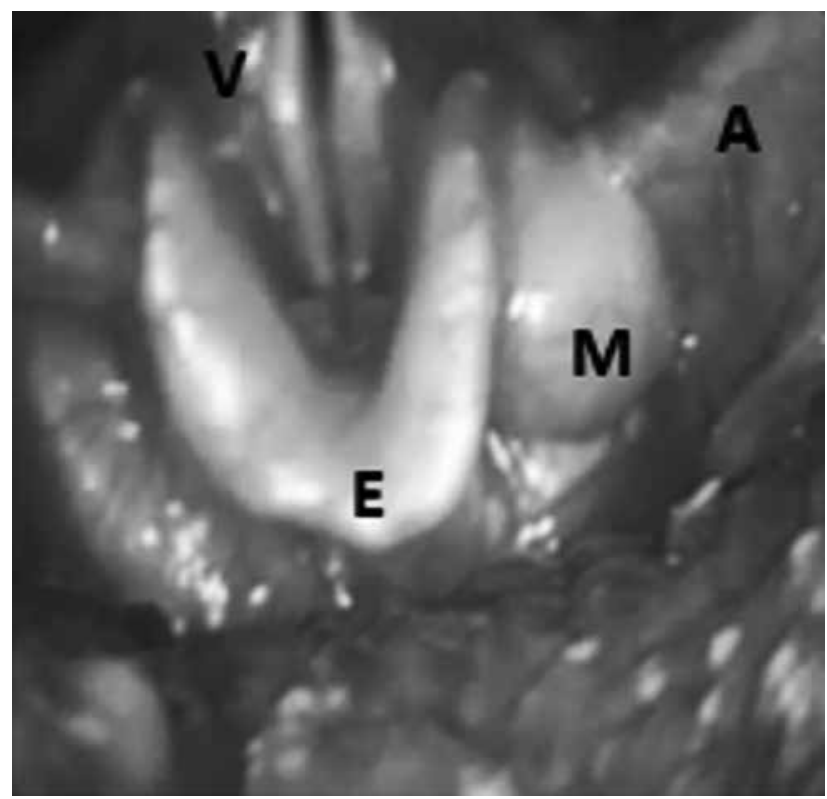

Figure 1. Laryngeal Endoscopic Image ( $V$; vocal cord, A; left aryepiglottic fold, E; epiglottis, M; mucoceles).

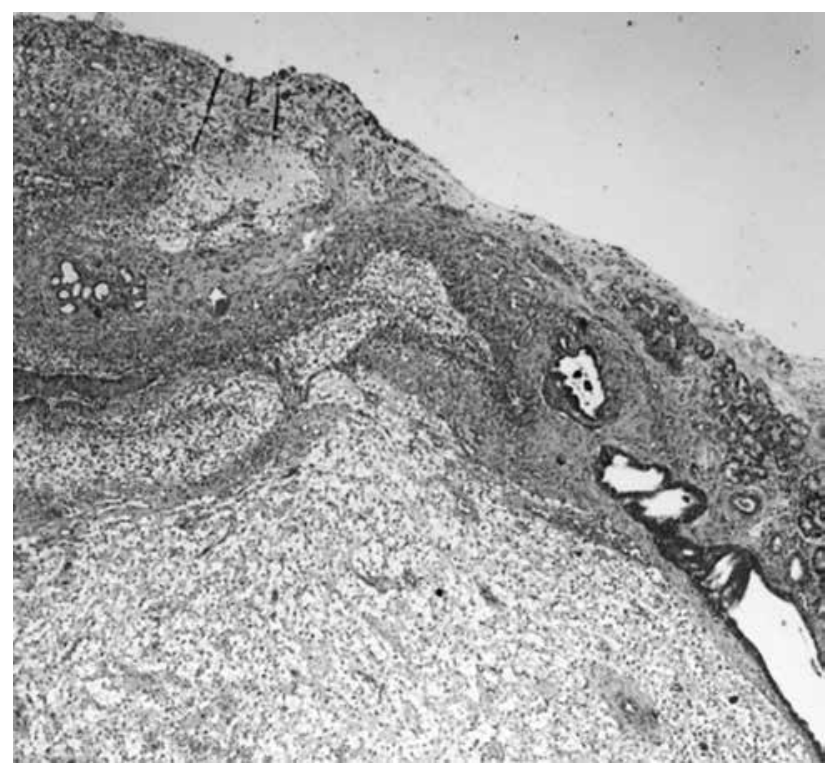

Figure 3. Minor salivary gland mucocele. (40 x hematoxylin/eosin).

\section{Discussion}

Mucocelles, the word meaning of "cavity filled with mucus", are frequently observed soft tissue lesions of the oral cavity ${ }^{1}$. More than $70 \%$ of mucoceles originate from minor salivary glands, and in the order of decreasing frequency, mucoceles are localized in the lower lip, in the cheek, at the base of the mouth, at the palate and on the tongue, but mucoceles can be seen in all places

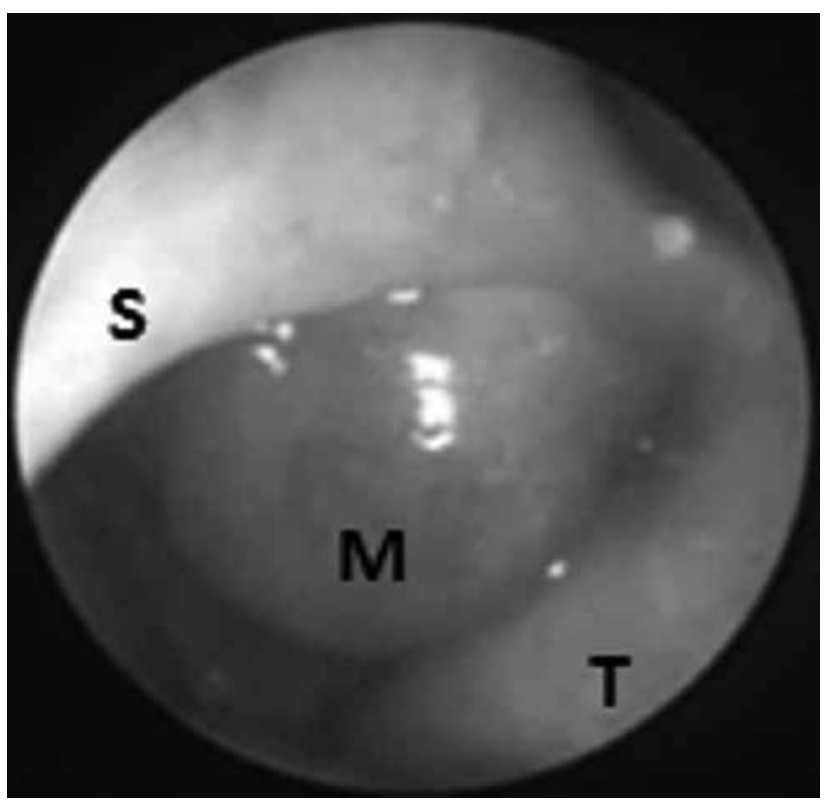

Figure 2. Nasopharyngeal Endoscopic Image (S; septum, T; left torus tubarius, M; mucoceles).

in which there is a salivary gland ${ }^{4}$ Clinically, they are painless asymptomatic lesions, which demonstrate fluctuations, and which generally occur in single form, although they can rarely be multiple in numbers ${ }^{1,5}$. In our case, there were multiple minor salivary gland mucoceles causing symptoms, located in the nasopharynx, filling the left rosenmüller fossa and on the left aryepiglottic fold in the hypopharynx neighboring the epiglottis, which is a very rare situation.

Common etiological factors effective in the formation of mucoceles are trauma, chronic biting and smoking, but they can also appear due to other etiological factors. In particular of the autoimmune diseases, Sjögren Syndrome has been reported to be closely related with development of mucocele ${ }^{6,7}$. In our case, the patient underwent evaluation with regard to autoimmune diseases and no findings consistent with autoimmune diseases was observed. There was no history of use of irritative substances or trauma in our patient.

The diagnosis of mucoceles is generally made clinically; however, the definitive diagnosis is made through histopathological assessment. Lipoma, lymphoepithelial cysts, lymphangioma, and mucoepidermoid carcinoma should be considered in the differential diagnosis ${ }^{1}$. In our case, the diagnosis of salivary gland mucosele was made through histopathological evaluation of the mass. 
The treatment of mucocele is surgical and the surgical method is determined according to the localization, size and its proximity to other anatomical structures. Small sized mucoceles are excised together with the related minor salivary gland $s^{1,3,8}$. Mid-sized mucoceles are dissected and removed, and larger mucoceles and mucoceles close to anatomical structures undergo marsupialization $^{1,3}$. In our case, due to the difficulty in access to the mucocele in the nasopharynx that had filled the left rosenmüller fossa, it was marsupialized through the endoscopic method, and the mucocele on the aryepiglottic fold in the hypopharynx neighboring the epiglottis was totally excised through direct laryngoscopy using a microscope. No recurrence was observed in the 2-year follow-ups of the patient.

Mucocele should be considered in the differential diagnosis of masses developing in the area of salivary glands, and the patient in whom the diagnosis of a mucocele is made, should undergo evaluation with regard to autoimmune diseases. Due to the fact that the mucoceles may ocur in multiple numbers, although rare, we suggest that patients diagnosed with mucocele should be evaluated through endoscopic imaging methods.

\section{References}

1. Baurmash HD. Mucoceles and ranulas. J Oral Maxillofac Surg 2003;61:369-78.

2. Schrefer J. Oral and Maxillofacial Pathology 2 nd ed. China: Saunders 2002.

3. Mark McGurk MD. Management of the ranula. J Oral Maxillofac Surg 2007;65:115-16.

4. Yamasoba T, Tayama N, Syoji M, Fukuta M. Clinicostatistical study of lower lip mucoceles. Head \& Neck 1990;12:316-20.

5. Anastassov GE, Haiavy J, Solodnik P, Lee H, Lumerman H. Submandibular gland mucocele: Diagnosis and management. Oral Surg Oral Med Oral Pathol Oral Radiol Endod 2000;89:159-63.

6. Campana F, Sibaud V, Chauvel A, Boiron JM, Taieb A, Fricain JC. Recurrent superficial mucoceles associated with lichenoid disorders. J Oral Maxillofac Surg 2006;64:1830-3.

7. Katayama I, Yamazaki S, Nishioka K. Giant mucocele of oral cavity as a mucocutaneous manifestation of Sjogren syndrome. J Dermatol 1993;2:238-41.

8. Rose EC, Rose C. Mucocele on the lower lip: A case report. J Orofac Orthop 2004;65:433-5. 